ISSN: $2450-6869$

eISSN: $2719-6763$

DEFENCE SCIENCE REVIEW

http://www.journalssystem.com/pno/

No. 11,2021

DOI: $10.37055 / \mathrm{pno} / 146918$

\title{
NATO Command System and Air Policing in the Polish Airspace
}

\section{Original article}

Received: 2021-10-03

Revised: $2022-01-18$

Accepted: 2022-02-24

Final review: 2022-02-22

\section{Peer review:}

Double blind

Keywords:

NATO structures, SHAPE, SACEUR, CAOC, Air Policing Mission

This work is licensed under the Creative Commons AttributionNonCommercial-NoDerivatives 4.0 License

\author{
Jacek Krawczyk ${ }^{1}, \mathrm{~A}-\mathrm{F}$ \\ ORCID (i) 0000-0001-6116-7099 \\ Marek Tomaszycki ${ }^{1,2}$ \\ ORCID (iD 0000-0001- 7952-0954
}

\begin{abstract}
${ }^{1}$ Department of Engineering, Helena Chodkowska University of Technology and Economics in Warsaw, Poland

${ }^{2}$ Military University of Land Forces in Wrocław, Poland

A - Research concept and design, B - Collection and/or assembly of data, C - Data analysis and interpretation, D - Writing the article, E - Critical revision of the article, $\mathrm{F}$ - Final approval of article
\end{abstract}

\section{Abstract}

Objectives: The article presents the NATO command structure with particular emphasis on the units responsible for command and control in the Polish airspace. The structure was described at three levels of command: strategic, operational and the tactical level. Moreover, the article also presents the issues concerning sovereignty in the space of the Republic of Poland and the cooperation of civil and military services in relation to the aircraft, which in an unauthorised manner crossed the state air border.

Methods: Scientific methods used in the paper are: analysis and criticism of written sources, analysis and logical construction.

Results: The article presents the structures of commands responsible for protection and defence of the airspace of NATO countries, their brief characteristics, command relationships and interdependencies between them and the main assumptions and objectives of the Air Policing mission, as well as the principles of implementation of this mission in the Polish airspace.

Conclusions: The main purpose of NATO's activities is to protect its member states, as a basis for preserving peace and strengthening international security. The organisational structures of the North Atlantic Treaty Organisation, based on three levels of command, are able to ensure the security of all 30 countries belonging to the alliance. The Polish airspace command system is fully compatible and integrated with the NATO system and in constant readiness to carry out combat missions, including the Air Policing Mission.

Corresponding author: Jacek Krawczyk- Department of Engineering, Helena Chodkowska University of Technology and Economins in Warsaw, Jagiellońska 82f, 03-301, Poland; email: jacek.krawczyk@uth.edu.pl 


\section{Introduction}

NATO (North Atlantic Treaty Organization) is a political-military organisation of North American and European states. NATO Headquarters, located in Brussels, Belgium, is the political headquarters of the alliance and the permanent home of the North Atlantic Council, NATO's main decision-making body, which includes 30 sovereign states.

As time passes, and the geopolitical and military situation in the world is changing, so are the requirements for the protection and defence of the airspace of the Member States, and thus, also for the North Atlantic Treaty Organisation. This is what, among other things, inspired the Authors to write this article.

The purpose of the alliance's activities is to stabilise the political situation in conflictprone regions and ensure the security of its member states in a defined area of operational responsibility and interest. It also aims to collectively protect its members as a basis for preserving peace and strengthening international security. According to the Washington Treaty, all member state undertakes to contribute to the development of peaceful and friendly international relations and to maintain its own security and that of other members of the Alliance and to strengthen its armed forces. The alliance is based on the principle of collective defence, in accordance with its basic premise, which states that an armed attack on one member is considered an attack against all members. The military activities of the alliance are implemented through the organisation of military commands at the strategic, operational and tactical levels of command.

The article presents the structures of commands responsible for protection and defence of the airspace of NATO countries, their brief characteristics, command relationships and interdependencies between them and the main assumptions and objectives of the Air Policing mission, as well as the principles of implementation of this mission in the Polish airspace. It may also have a positive impact on the implementation of both the protection and defence of the airspace of the Republic of Poland, and above all on the understanding of the discussed issues in a broadly understood military, civilian and even expert environment.

In order to make a proper diagnosis, the following methods were used: literature analysis and criticism, heuristic method, descriptive method, participant observation, comparative method. The sources of information used for the research included documents available on the Internet, various publications, Authors' own translations, and discussions with experts.

It should be remembered that the most valuable data for the topic in question are sensitive and cannot be published in a publication open to the public, so the article is an 
attempt to bring the subject closer to the public within the framework allowed by the legislation.

\section{Strategic level of command}

At the strategic level (Figure 1), the NATO Command Structure (NCS) comprises two commands. First - Allied Command Operations (ACO), responsible for the planning and execution of all NATO operations, and the second - Allied Command Transformation (ACT), responsible for NATO training and transformation.

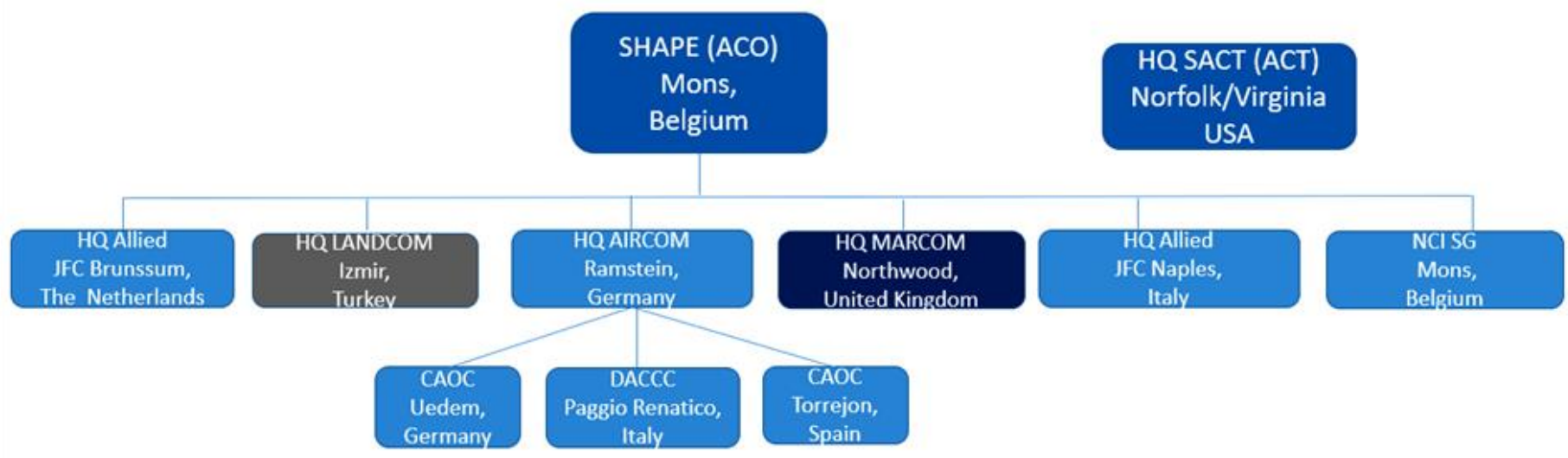

Figure 1. NATO command structure

Source: Military Command Structure, 2021

Allied Command Transformation (ACT) Norfolk (United States) is responsible for testing and implementing a new strategic doctrine, reviewing NATO capabilities and capacities, and conducting training and exercises. It develops the capabilities of allied forces undertaken in response to current and projected threats to international security.

ACT's core areas of activity:

- defence planning with regard to long-term requirements,

- development of concepts and doctrines at the strategic level,

- developing international capabilities to fulfil the tasks of the Alliance,

- conducting analyses of directions of development of NATO intelligence concepts and capabilities,

- developing strategies, concepts, capabilities of systems and their structures,

- training, exercises and control,

- research, experimentation and development of future technologies. 
Allied Command Operations (ACO) Mons (Belgium) is responsible for planning and conducting military operations to ensure security. In the event of a military crisis or war, it is responsible for the use of military means.

The key areas of ACO activity:

- to prepareoperation plans,

- to create and organise forces and conduct of allied activities,

- to generate strategic concepts for the development of armed forces,

- to define defence planning and military policy priorities,

- to develope concepts and directives for the full range of Alliance tasks, to create joint command and force structures.

The ACO is a three-tier command with headquarters and supporting elements at the strategic, operational and tactical levels. It exercises C2 over permanent and deployed commands, as well as allied combined forces, including those assigned to carry out alliance military missions. Allied Combined Forcesare structures of two or more types of armed forces from at least two alliance countries, operating under a single command consisting of representatives from different countries.

Supreme Headquarters Allied Powers Europe (SHAPE) - based in Casteau near Mons, Belgium - is a command post (ACO) commanded by the Supreme Allied Commander Europe (SACEUR). It is a position reserved for a representative of the United States with the rank of general (four-star general). SACEUR has a dual position: he is the commander of the United States European Command (EUCOM) and the Supreme Allied Commander of NATO forces in Europe. SACEUR organises overall command of operations at the strategic level. In addition, he gives strategic military direction to subordinate commands and is responsible for the preparation and execution of all alliance military operations, both routine military and non-military.

In terms of commanding NATO troops, it answers to the Military Committee (MC), which is the highest military body in NATO under the overall political authority of the North Atlantic Council (NAC) and the Nuclear Planning Group (NPG). The Military Committee is the main source of advice to the NAC and the NPG.

\section{Operational level of Command}

The operational level consists of two components: Allied Joint Force Commands (JFCs): one in Brunssum, the Netherlands, and the other one in Naples, Italy. They must be prepared to plan, conduct and sustain NATO operations of varying size and scope, both collective 
defence missions and crisis response operations. In fact, they must be able to manage a joint operation from their fixed locations in Brunssum or Naples or from a prepared Command Post when operating directly in the theatre. In the latter case, the deployed headquarters is called Joint Task Force HQ (JTFHQ) and should be able to operate for a maximum of one year. The JFC is only responsible for executing one operation at a time. However, JFC elements that are not deployed can provide support to other operations and missions. When the JFC is not activated to conduct operations, it can support ACO in performing ongoing tasks, such as training and preparing for future operations (including crisis operations). The commands are also responsible for working with key regional partners and organisations to support the delivery of regional ACO tasks and responsibilities in accordance with SACEURA guidance. In addition, they support cooperation with partners participating in NATO operations and support prepare partner countries for NATO membership.

\section{Tactical level of Command}

Allied Air Command (HQ AIRCOM), located in Ramstein, Germany, is the highest level of air command in NATO. The task of the command is to plan and direct the air component and the air and missile defence component during alliance operations and missions. It is the principal advisor to the alliance and in the area of Air Force issues (air forces, air and missile defence and radio technical forces) contributes to the planning of their development and transformation. HQ AIRCOM, with appropriate support from the NATO command structure, can provide $\mathrm{C} 2$ for a small joint air operation from its permanent location, i.e. from Ramstein, or it can act as an Air Component Command to support Major Joint Operations (MJO). The structure of the air commands reporting directly to HQ AIRCOM is shown in Figure 2. The full system of command and control (Coyle, 1987; Liao, 2008) air organisation under the command of HQ AIRCOM includes over 50 Control and Reporting Centres (CRC), as well as radar and civil air traffic control units (Zajkowski, 2020), directly under NATO as well as national commands. 


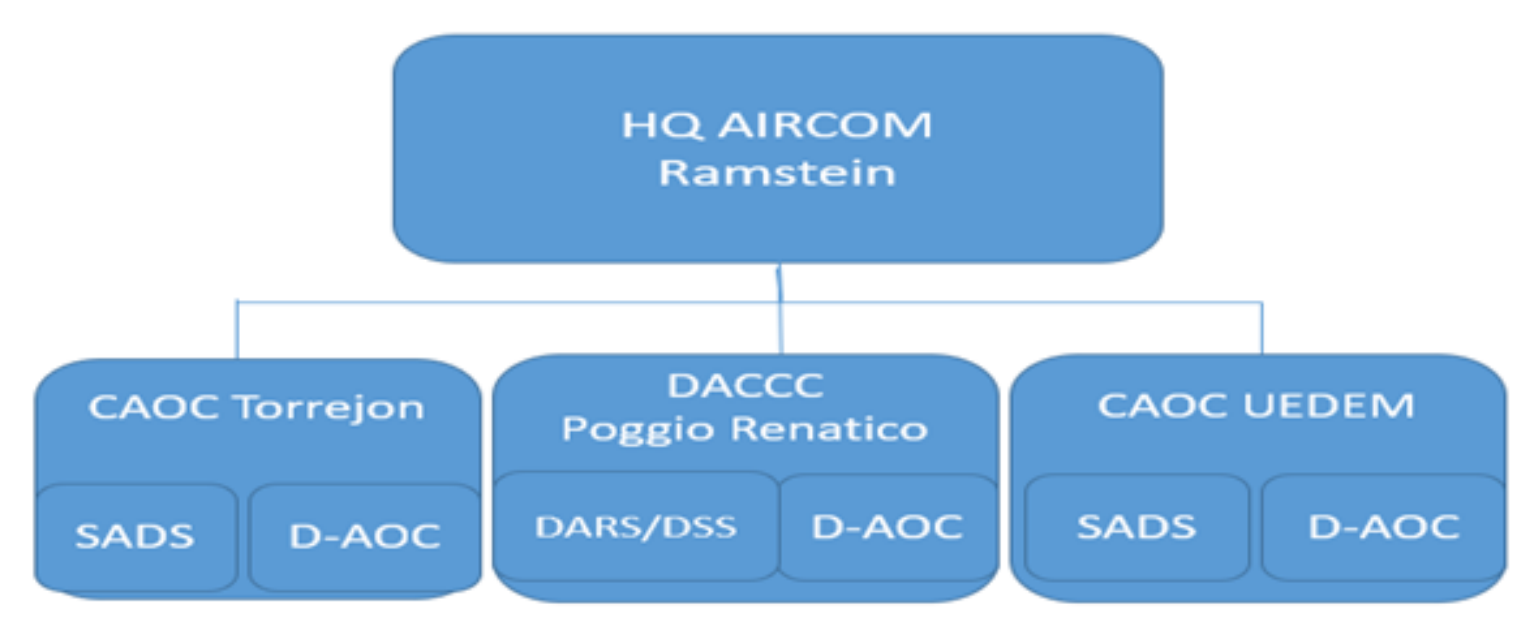

Figure 2: Structure of air commands at the tactical level Source: Military Command Structure, 2021

Combined Air Operations Centres (CAOC) are hybrid units, consisting of a Static Air Defence Centre (SADC) and a Deployable Air Operations Centre (D-AOC). CAOC commands focus on Air Policing (AP) mission responsibilities and form the backbone of collective defence operations in the NATO area of responsibility. In times of crisis or during operations, the SADC continues the AP mission while D-AOC personnel reinforce the HQ AIRCOM Joint Force Air Component (JFAC) organisation, which normally remains in Ramstein, Germany. They are located in Uedem (Germany) and Torrejon (Spain). The Deployable Air Command and Control Centre (DACCC), located in Poggio Renatico (Italy), is a hybrid entity that consists of three elements: Deployable Air Control Centre, Recognized Air Picture Production Centre / Sensor Fusion Post (DARS), Deployable Air Operation Centre (D-AOC) and Deployable Sensors Section (DSS). During peacetime, the DACCC will be responsible for the initial operation and training of assigned NCF JFAC personnel from both HQ AIRCOM and D-AOC.

\section{Combined Air Operations Centre (CAOC)}

The latest reorganisation of NATO's command structure in 2013 reduced the number of CAOC units to two: CAOC TORREJON and CAOC UEDEM. CAOC UEDEM, is responsible for NATO air operations north of the Alps and CAOC TORREJON south. Each has a Static Air Defence Centre, maintaining readiness for Air Policing Missions, and a Deployable Air Operations Centre (D-AOC) for contingency operational tasks such as the provision of qualified personnel in the NATO Command Structure Joint Force Air Component extension at Ramstein (Kołata, 2019). 
Combined Air Operations Centre TORREJON (CAOCTJ) is headquartered at Torrejón Air Force Base, north of Madrid. The main mission of the CAOCTJ is to plan, direct, coordinate, monitor, analyse and command air operations using air assets assigned to AP Missions in peacetime, in accordance with NATO's Allied Air Command guidelines. It implements NATO Air Policing operations in Albania, Slovenia and Montenegro.

The Combined Air Operations Centre UEDEM is based in Uedem, Germany. Most of the CAOC UEDEM support functions are carried out by the nearby Von-Seydlitz Kalkar Barracks. National support units from Belgium, the Netherlands and the United States are also located there. In addition, the CAOC UEDEM is home to the NATO Communications and Information Agency (NCIA) Detachment. CAOC UEDEM is resourced with personnel from 18 countries. The position of commander is rotated between Germany and Belgium, while representatives from Poland and Germany alternate in the position of deputy commander.

For air operations, CAOC UEDEM works closely with Control and Reporting Centres and National Air Policing Centres responsible for Air Policing missions, enabling close coordination of operations, procedures, command and control in peacetime. In addition, it maintains control over the NATO Baltic Air Policing operation, in which the participating NATO countries rotate the provision of rapid response forces for the protection and defence of the airspace of Lithuania, Latvia and Estonia, as well as the airspace of Iceland on an ad hoc basis. Air Policing duties are carried out year-round on a four-month cycle.

\section{Deployable Air Command and Control Centre (DACCC)}

Headquartered in Poggio Renatico (Northern Italy) Deployable Air Command and Control Centre (DACCC) is a hybrid entity comprising the Deployable Air Control Centre, the Recognized Air Picture Production Centre/Sensor Fusion Post (DARS), the Deployable Sensor Section (DSS) and the Deployable Air Operations Centre (D- AOC). The mission of the DACCC is to prepare the DARS / DSS / D-AOC to move and perform tasks as a Joint Force Air Component (JFAC) across the theatre of operations, providing highly trained experts to complement AIRCOM during operations and exercises.

HQ LANDCOM Izmir (TURKEY) is the permanent headquarters of NATO land forces. The LANDCOM commander is an advisor to the Alliance on the conduct of land operations.

The main task of LANDCOM is to ensure the interoperability of NATO land forces. The command is responsible for ensuring the smooth and rapid participation of land components for a joint operation. LANDCOM will also handle the planning, conduct and direction of land operations. If a corps landing operation is underway. The corps is likely to cooperate with JFC 
Brunssum or JFC Naples.

HQ MARCOM Northwood (UK) is the central command for all NATO naval forces. The MARCOM Commander is the principal maritime advisor to the Alliance. Under the command of SACEUR, it forms the core of the command responsible for conducting maritime operations.

The Allied Maritime Command (HQ MARCOM) manages NATO's four standing maritime groups. These are multinational, integrated naval forces comprising ships from allied nations that are available to NATO in support of Alliance tasks. These groups ensure NATO's continued maritime capability by providing continuous support to NATO missions. MARCOM is the central command for all NATO naval forces and the MARCOM Commander is the Alliance's Chief Maritime Advisor.

Like its land and air counterparts (LANDCOM and AIRCOM), MARCOM directly corresponds to NATO's Allied Command of Operations (ACO), which is located in Mons, Belgium. The command is headquartered in the London suburb of Northwood where Royal Navy units are also located.

The NATO Communications and Information Agency (NCI Agency) provides NATO's core network services for operational and exercise support undertakings and programme management.

The NATO Communication and Information Systems Group (NCISG), affiliated to Allied Command Operations, provides mobile communications and information systems for the onward deployment of elements of the NATO Command Structure and NATO Joint Task Force Command.

The central elements of the NCI are divided between Brussels, Mons and The Hague. The Director General is based in Brussels, where he works with Alliance representatives within his area of responsibility.

NCI Agency areas of responsibility include:

- Command and control services,

- Education and training,

- Exercise and operations support,

- Operational analysis, defence planning,

- $\mathrm{C} 2$ of air and missile defence,

- NATO consultation and command networks,

- Combined intelligence, surveillance and reconnaissance, 
- iGeoSIT,

- Cyber-security services.

\section{NATO Air Policing Mission (AP MISSION)}

AP MISSION is one of NATO's key peacetime operations. Maintaining the integrity of the alliance's airspace is a joint airspace defence task that requires NATO to take action against any breaches using agreed procedures. NATO Air Policing includes the use of Air Surveillance and Control System (ASACS), Air Command and Control (Air C2) and fighter aircraft designed for interception (Radomska, 2019, pp. 287-312). NATO's airspace control operations involve the continuous readiness on the ground ( 24 hours a day, 365 days a year) of an armed interceptor fighter aircraft, which must respond to any unusual aerial activity, such as the presence of an unidentified aircraft approaching or violating the law in Alliance airspace. In such a case, the aircraft is authorised to approach towards the unidentified aircraft in order to identify it, establish communication if possible and take appropriate action if necessary.

In addition, the mission is also carried out in order to protect the population and armed forces from an air attack and to provide assistance to the crews of aircraft in distress.

\section{Air Policing in Polish airspace}

The Act of 12 October 1990 on the Protection of the State Border (Journal of Laws of 2019, item 1776, art. 6) stipulates that the Republic of Poland exercises its sovereignty over the land territory and subsoil, the internal maritime waters and the territorial sea and the bed and subsoil, as well as in the airspace above the land territory, the sea territory, the internal waters and the territorial sea.

The course of the state border on land and the demarcation of internal sea waters and the territorial sea with neighbouring states are defined in international agreements concluded by the Republic of Poland. The state border at sea runs at a distance of 12 nautical miles from the base line, specified in separate regulations, or along the outer road included in the territorial sea.

\section{Crossing of the aerial state border by a foreign state aircraft}

According to the Convention on International Civil Aviation of 7 December 1944, OJ of 26 June 1959, item 212, Article 3c ${ }^{1}$ - no State aircraft of a Contracting State shall fly over or

${ }^{111}$ Convention on International Civil Aviation, signed at Chicago on 7 December 1944. (Journal of Laws 1959, No. 35 , item 212). 
land in the territory of another State without authorisation by special agreement or otherwise or in contravention of the terms of such authorisation. In the absence of such authorisation, the provisions of the Convention may apply.

The subdivision of aircraft is based on their intended use:

a) aircraft used by the Armed Forces (military aircraft);

b) aircraft used by organisational units of the Border Guard, the Police and the State Fire Service -law enforcement aircraft (Krawczyk, 2018, p. 1).

Article 18b (1) of the State Border Protection Act states that foreign civil and military aircraft may be requested by a state air traffic management authority to leave the airspace of the Republic of Poland, to change the direction or altitude of the flight accordingly, to land at a designated airport or to carry out other instructions aimed at stopping the violation of the airspace.

In the event of failure to comply, the aircraft may be intercepted by military aircraft and subjected to identification, including attempts to establish radio contact and visual contact for the purpose of orienting the aircraft in the correct heading or altitude, or to force a landing at a designated aerodrome ${ }^{2}$. If a foreign military aircraft fails to comply with any of the calls and commands, it may be warned by warning shots, and if it continues to fail to comply with the instructions of the intercepting aircraft's crew, it may be destroyed. This regulation also applies to foreign civil aircraft, but only if on board there are exclusively persons intending to use the aircraft as a means of a terrorist attack.

\section{Command}

The highest command authority of the Polish Air Force is the Air Operation Centre-Air Component Command (AOC - ACC), directly subordinated to the Operational Command of the Armed Forces. According to Figure 3 AOC - ACC are subordinate to: 22nd Command and Guidance Centre (CGC); Mobile Air Operations Command Unit (MAOCU); 1st Regional Command and Guidance Centre (RCGC); Air Operations Coordination Centres (APCC) and assigned forces and assets on combat duty.

\footnotetext{
${ }^{2}$ Annex 2 to the Convention on International Civil Aviation. Air traffic regulations.
} 


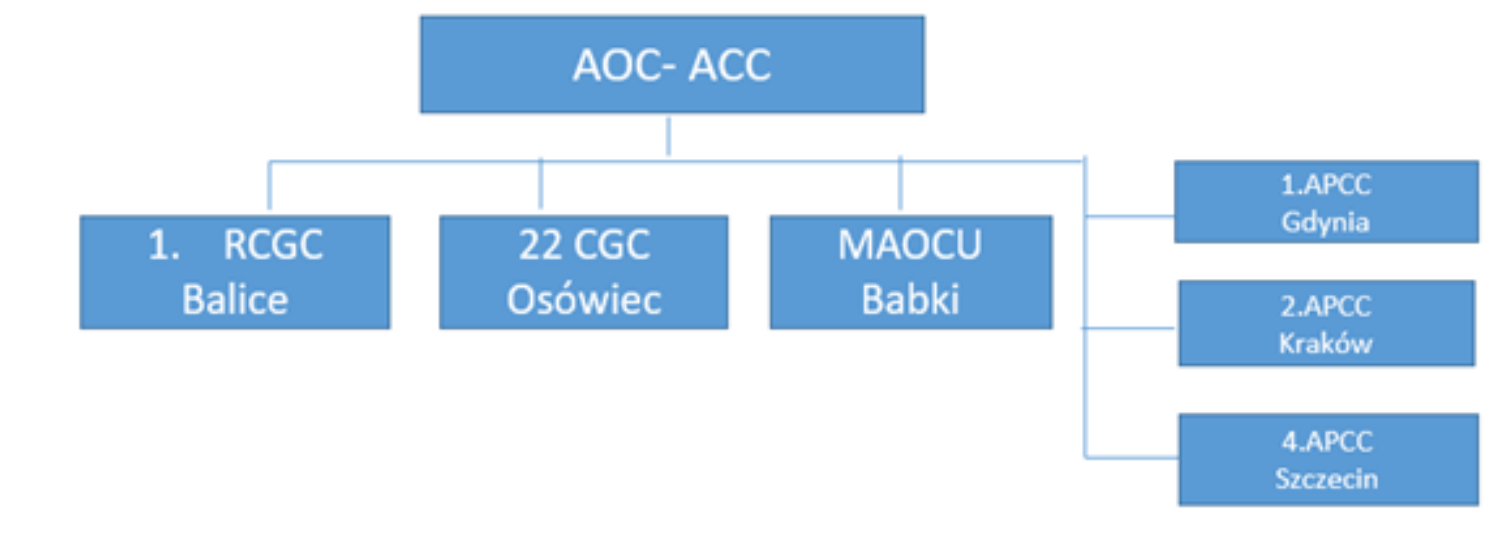

Figure 3. Command structure of Polish Air Force Source: Own work.

The allocated forces and resources may be directed and commanded by the operational staff of the AOC - ACC as well as by AWACS (Airborne Warning and Control System). The accepted abbreviations for an early warning aircraft performing surveillance tasks as part of airspace control are AEWAC, AEW\&C and the aforementioned AWACS.

The AWACS system has the capability of detecting objects performing air operations at low altitude, which is its advantage over radar stations whose detection is limited by terrain obstacles, landforms, which may have an impact on reflections and wave refractions. There may also be interference with radar operation, or even obscuring the object from radar waves.

Performance of airspace control tasks by AWACS results in an increase in the detection range of objects including aircraft and missiles flying at different altitudes. Rapid detection of such objects allows for a timely response of the air defence system to counteract violations of airspace boundaries, flight contrary to the conditions granted or direct and indirect threats to the population and security of the States Parties to the Agreement.

In the area of interoperability, comparing the national and allied air force command systems, it should be noted that they have similar command authorities. In the national solutions the equivalent of Allied Air Command HQ is Air Operation Centre-Air Component Command. Subordinate to ACC - ACC are Command and Control Centre and Regional Command and Control Centre, which are compatible with Control and Reporting Center CRC (Grenda, 2014, p. 158; Kołodziejczak, 2020).

\section{Coordination of Air Policing missions}

During the deployment of the Air Policing mission, the Air Operation Centre - Air Command Components and the Polish Air Navigation Services Agency (PANSA) cooperate with each 
other. Functional persons exchange information among themselves or authorise cooperation of subordinate personnel.

PANSA, through cooperation with Air Traffic Management Centres of neighbouring countries, receives information about aircraft that have been assigned the RENEGADE status or are likely to be assigned such status and are flying towards the Polish airspace. Information on the above-mentioned flight is immediately provided to the AOC - ACC, which implements the optimal variant of the Air Policing mission. Procedures are carried out in accordance with the Agreement on Operational Cooperation between the Polish Air Navigation Services Agency and the Air Operations Center - Air Command Component with regard to the conduct of the Air Policing mission .

The RENEGADE status is given to a civilian aircraft that has crossed the air state border, or flies in the airspace of the Republic of Poland without permission or contrary to the conditions of permission and has not complied with the summons referred to in Article $18 \mathrm{~b}$ (1) of the Act on the Protection of the State Border and may be used as a means of aerial terrorist attack. The qualification of an aircraft to the RENEGADE category is made by the Duty Commander of Air Defence (DCAD). The aircraft described above may be classified into three categories: "Suspected RENEGADE", "Probable RENEGADE" or "Confirmed RENEGADE". These categories are based on the risk posed by aircraft which do not comply with procedures or instructions from Air Traffic Management or Aviation Command (Bolić and Ravenhill, 2021). Aircraft on combat duty in the Air Policing mission perform flight operations in ALFA (combat) and TANGO (training) zones. The ALFA areas are defined by latitude and longitude. Activation and deactivation of ALFA zones is decided by the AOC-ACC officer in consultation with the Air Traffic Controller Supervisor. An ALFA zone, located in controlled space, becomes active for QRA(I) (Quick Reaction Alert Interception) action in that zone only when all aircraft in controlled traffic have been moved out of its horizontal or vertical boundaries. Combat operations in an ALFA zone are undertaken on the ALFA SCRAMBLE signal. ALFA active zones are unclassified airspace (unclassified airspace class - airspace structures in which an authorised entity is responsible for safety .

TANGO zones are used exclusively for training Air Policing missions. They are built on the basis of TSA zones (Temporary Segregeted Area) (Bielawski and Polkowska, 2020) in an unclassified class of airspace. The execution of the Air Policing mission in the TSA is carried out on the basis of current airspace coordination by the AOC - ACC and PANSA services. 
Once an aircraft is classified as RENEGADE, operational services from the AOC - ACC and PANSA cooperate to ensure safety in the airspace and on the ground. Aircraft with the RENEGADE status are observed and an analysis is made on an ongoing basis in order to take appropriate decisions in relation to countering the threat from the air. Military, non-military and civilian services are informed about their possible use and the status of the current threat. PANSA air traffic control and airspace management services secure the airspace in such a way as to optimally isolate the remaining air traffic from RENEGADE-rated aircraft in the direction of their flight and in the airspace where they are likely to perform flight operations, including approach procedures for landing. The authorities of the cities in which the air risk procedure is activated shall also be informed. Coordinating the activities of the services after a RENEGADE category has been assigned to an aircraft is extremely difficult and complex. Military services, the non-military system and state administration are involved (Radomyski and Kulik, 2018). In addition, civilian foreign institutions and military bodies, as well as the operational services of neighbouring countries, are involved in the coordination process.

In order for this type of undertakings to be coordinated quickly and safely, it is necessary to carry out recurrent exercises and trainings, to apply appropriate procedures and to analyse cases of previous incidents of a particular type, with drawing conclusions from the cases.

\section{Conclusions}

The main purpose of NATO's activities is to protect its member states, as a basis for preserving peace and strengthening international security. The organisational structures of the North Atlantic Treaty Organisation, based on three levels of command, are able to ensure the security of all 30 countries belonging to the alliance.

The organisation of military command structures allows the implementation of military and peacekeeping tasks across the globe. The structures are composed of representatives of various countries, whose units are deployed in strategic places, which is additionally supposed to ensure the security of citizens of the countries where the alliance soldiers are present. This is one of the elements of gaining the confidence of the international community in NATO and a component of strategic deterrence against a potential adversary.

The member states are obliged to implement projects that will result in the development of peaceful and friendly international relations and the preservation of their own and other alliance members' security. In addition, the authorities of the alliance as well as member states 
are obliged to strengthen their own and collective military potential and take care of its systematic development.

The Polish airspace command system is fully compatible and integrated with the NATO system and in constant readiness to carry out combat missions, including the Air Policing Mission.

During the implementation of the NATO Air Policing Mission, an important factor affecting safety is appropriate civil-military cooperation, which should be systematically developed through the organisation of joint training, integration of civil and military air traffic management systems and exchange of radiolocation information. This cooperation must be carried out at all levels of command of the alliance, international organisations such as ICAO or EUROCONTROL, as well as by national management structures, both at the central and local levels.

\section{References}

Bielawski, R. and Polkowska, M. (2020) Organisational, Military and Legal Aspects of Space Security. Warszawa: Wydawnictwo Akademii Sztuki Wojennej.

Bolić, T. and Ravenhill, P. (2021) 'SESAR: The Past, Present, and Future of European Air Traffic Management Research', Engineering, 7(4), pp. 448-451. doi: 10.1016/j.eng.2020.08.023.

Coyle, R. G. (1987) 'A model for assessing the work processing capabilities of military command and control systems', European Journal of Operational Research, 28(1), pp. 27-43. doi: 10.1016/0377-2217(87)90167-6.

Grenda, B. (2014) System Walki Sił Powietrznych Rzeczypospolitej Polskiej. Warszawa: Ementon.

Kołata, G. (2019) 'Airbase as Defended Asset for Air Defense', Safety \& Defense, 5(1), pp. 37-45. doi: 10.37105/sd.41.

Kołodziejczak, M. E. (2020) Funkcjonowanie Naczelnego Dowódcy Sił Zbrojnych w Rzeczypospolitej Polskiej. Warszawa: Wydawnictwio Akademii Sztuki Wojennej.

Krawczyk, J. (2018) 'The Crossing of a State's Air Border by State-Owned and Civilian Authorized and Unauthorized Aircraft', Przegląd Nauk o Obronności, (6), pp. 16-27. doi: $10.37055 / \mathrm{pno} / 118857$.

Liao, S. H. (2008) 'Problem structuring methods in military command and control', Expert Systems with Applications, 35(3), pp. 645-653. doi: 10.1016/j.eswa.2007.07.012. 
Military

https://shape.nato.int/military_command_structure.

Radomska, A. (2019) 'Techniczne, militarne i naturalne aspekty bezpieczeństwa w przestrzeni powietrznej', in Bielawski, R., Solarz, J., and Miszewski, D. (eds) Współczesne i przyszłe zagrożenia bezpieczeństwa. Cz. 1. Warszawa: Wydawnictwo Akademii Sztuki Wojennej.

Radomyski, A. and Kulik, T. (2018) 'Air safety environment of the state', in Radomyski, A., Malinowski, P., and Michalski, D. (eds) Identification of a state's air security environment. Wrocław: GRAFPOL Agnieszka Blicharz-Krupińska.

Zajkowski, R. (2020) 'The Principles and Organization of Air Traffic in Military Operations: Experiences from the Mission in Iraq', Safety \& Defense, 6(1), pp. 77-88. doi: $10.37105 / \mathrm{sd} .66$. 